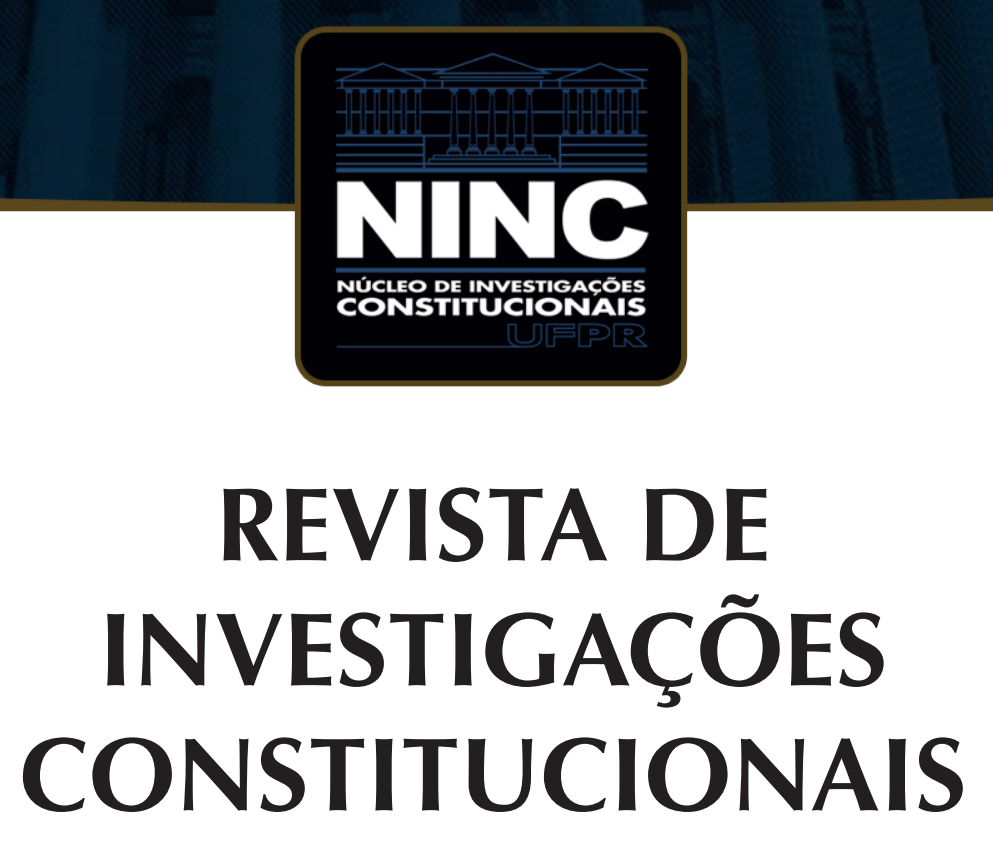

JOURNAL OF CONSTITUTIONAL RESEARCH

vol. 7 | n. 3 | setembro/dezembro 2020 | ISSN 2359-5639 | Periodicidade quadrimestral Curitiba | Núcleo de Investigações Constitucionais da UFPR | www.ninc.com.br 


\title{
Disaggregating dismemberment: nullity, natality, and the hollowing of constitutional renewal in designed written constitutionalism
}

\section{Desagregando desmembramento: nulidade, natalidade $e$ o esvaziamento da renovação constitucional no constitucionalismo escrito}

\author{
MING-SUNG KUO \\ ' University of Warwick (Coventry, United Kingdom) \\ M-S.Kuo@warwick.ac.uk \\ https://orcid.org/0000-0001-8400-0451 \\ Recebido/Received: 12.04 .2020 / April 12 $2^{\text {th }}, 2020$ \\ Aprovado/Approved: $17.10 .2020 /$ October $17^{\text {th }}, 2020$
}

\begin{abstract}
This paper aims to rethink the idea of constitutional renewal through a dissection of Richard Albert's ground-breaking concept of constitutional dismemberment. It is contended that under the rubric of constitutional dismemberment are two exceptional constitutional phenomena: the ought-to-be declared nullity of unconstitutional constitutional amendments and the legal unity-defying, extraconstitutional expression of what Hannah Arendt called "natality" in political action. The thesis is that attempts to tame revolutionary constitutional alteration with designed rules as to formal constitutional change as Albert's illustrates are missing the meaning of constitution-making for a natality-driven constitutional renewal characteristically defies designed constitutional form. The concept of constitutional dismemberment is first dissected in light of Arendt's idea of natality. With constitutional dismemberment unpacked,
\end{abstract}

Resumo

O objetivo deste trabalho é repensar a ideia de renovação constitucional através de uma análise do inovador conceito de desmembramento constitucional de Richard Albert. Alega-se que, sob a rubrica do desmembramento constitucional, há dois fenômenos constitucionais excepcionais: a necessária declaração de nulidade de emendas constitucionais inconstitucionais e a extraconstitucional expressão do que Hannah Arendt chamou de "natalidade" em ação política. A tese é que tentativas de domar as alterações constitucionais revolucionárias através de regras desenhadas como mudanças formais à Constituição, como mostrado por Albert, carecem do significado de constitution-making para uma renovação constitucional guiada pela natalidade, desafiando a forma do constitucionalismo desenhado. O conceito de desmembramento constitucional é primeiro analisado sob a luz da ideia de natalidade de Arendt. Após isso, na sequência observa-se que o constitution-making

Como citar esse artigo/How to cite this article: KUO, Ming-Sung. Disaggregating dismemberment: nullity, natality, and the hollowing of constitutional renewal in designed written constitutionalism. Revista de Investigações Constitucionais, Curitiba, vol. 7, n. 3, p. 773-794, set./dez. 2020. DOI: 10.5380/rinc.v7i3.72831.

"Associate Professor at the University of Warwick (Coventry, United Kingdom). Holds a Doctor of the Science of Law (J.S.D.) and an LLM from Yale University (New Haven, United States). E-mail: M-S.Kuo@warwick.ac.uk. 
it is further observed that the constitution-making transmutes into the formal pronouncement of a new codified constitution in Albert's rigid tripartite classification of constitutional changes into amendment, dismemberment, and enactment. Albert therefore inadvertently reduces constitution-making to the formal enactment of a new codified constitution with constitutional natality dismembered and constitutional renewal hollowed out. It is concluded that Albert's formalistic conceptual framework of constitutional change reflects the centrality of comparative written constitutions in the place of comparative constitutional phenomena in current comparative constitutional studies.

Keywords: constitutional renewal; constitutional dismemberment; constitutional amendment; Richard Albert; natality. se transmuta em pronunciamentos formais de uma nova Constituição codificada na rígida classificação tripartida de Albert em emenda, desmembramento e promulgação. Albert, assim, inadvertidamente reduz o constitution-making à promulgação formal de uma nova Constituição codificada com natalidade constitucional desmembrada e renovação constitucional esvaziada. Conclui-se que o conceito formalista de Albert sobre mudança constitucional reflete a centralidade da comparação de constituições escritas no lugar da comparação de fenômenos constitucionais nos atuais estudos de direito comparado.

Palavras-chave: renovação constitucional; desmembramento constitucional; emenda constitucional; Richard Albert; natalidade.

\section{CONTENTS}

1. Introduction; 2. Dismemberment disaggregated: constitutional amendment on trial; 3 . When constitution-making becomes constitution-writing: constitutional natality dismembered; 4. In lieu of conclusion: constitution-making is more than constitutional design; 5. References.

\section{INTRODUCTION}

Richard Albert takes studies of constitutional change to another level with his erudite work "Constitutional Amendments."1 As he sets out in the beginning, the objective of Constitutional Amendments is "to bring formal amendment back to the center of the field of constitutional change." ${ }^{2}$ This reveals Albert's ambitious project "to guide those seeking to understand how constitutions change" with the hopes for "inspir[ing] interest in constitutional amendment." ${ }^{3}$ Notably, Albert's target audience is not li-

\footnotetext{
ALBERT, Richard. Constitutional Amendments: Making, Breaking, and Changing Constitutions. Oxford and New York: Oxford University Press, 2019. In line with Albert's usage, I use constitutional change and constitutional alteration interchangeably, which include what Albert calls constitutional amendment (proper) and constitutional dismemberment unless otherwise specified. Notably, as suggested throughout Constitutional Amendments, constitutional change may take place formally and informally. Formal constitutional change refers to the direct alteration of the text of the codified constitution or other constitutional laws sitting on the top order of the hierarchical legal system; informal constitutional change refers to such alterations taking place through judicial interpretation, legislative enactment, or political practice. Both formal and informal constitutional change/ alteration include amendment and dismemberment. Unless otherwise specified, my discussion centers on formal constitutional change. As regards another form of constitutional change - the making of a new constitution, it is referred to as constitutional replacement. All forms of constitutional change are considered the means of constitutional renewal.

2 ALBERT, Richard. Constitutional Amendments: Making, Breaking, and Changing Constitutions. Oxford and New York: Oxford University Press, 2019, p. 2.

3 ALBERT, Richard. Constitutional Amendments: Making, Breaking, and Changing Constitutions. Oxford and New York: Oxford University Press, 2019, p. 36.
} 
mited to those living in the ivory tower. "[L]eaders involved in making or remaking their constitution" are also whom Constitutional Amendments is pitching. ${ }^{4}$ Guided by the foregoing goals, Albert presents us - yes, those living in the ivory tower - with a 360-degree study of formal constitutional amendment. Standing out from the already crowded field of constitutional change, ${ }^{5}$ Constitutional Amendments rests on Albert's ground-breaking discovery of "constitutional dismemberment" amidst manifold formal constitutional alterations aimed at constitutional renewal. ${ }^{6}$

Notably, applying his theory to constitutional practice with the leaders involved in constitution-(re)making in mind, Albert suggests that constitutional identity-changing dismemberment ${ }^{7}$ be constitutionalized alongside amendment in the design of the constitutional rules governing formal changes so that transformative and revolutionary constitutional alterations can take place without disrupting "legal continuity," while the rule of law can therefore be upheld. ${ }^{8}$ As will be revealed, Albert moves between roles in three dimensions in Constitutional Amendments: constitutional designer vs constitutional comparatist; substantivist vs formalist; general constitutional theorist vs written constitutionalism defender. Reflecting its author's multiple identities, Constitutional Amendments is not only erudite but also intricate. Thus, in answering Albert's call for further inquiry into constitutional change, ${ }^{9}$ my contribution surely falls far short of engaging with his encyclopaedic work on constitutional change comprehensively. Rather, I aim to rethink the idea of constitutional renewal through an engaged dissection of Albert's newly discovered, yet-to-be-explored constitutional dismemberment in the world of formal (or codified) constitutional change.

4 ALBERT, Richard. Constitutional Amendments: Making, Breaking, and Changing Constitutions. Oxford and New York: Oxford University Press, 2019, p. 36.

5 See, e.g., ACKERMAN, Bruce. We the People. vols. 1-3. Cambridge: Belknap, 1991-2014; ACKERMAN, Bruce. Revolutionary Constitutions: Charismatic Leadership and the Rule of Law. Cambridge: Belknap, 2019; ARATO, Andrew. Civil Society, Constitution, and Legitimacy. Lanham, MD: Rowman \& Littlefield, 2000; ARATO, Andrew. Post Sovereign Constitution Making: Learning and Legitimacy. Oxford: Oxford University Press, 2016; ARATO, Andrew. The Adventures of the Constituent Power: Beyond Revolutions? Cambridge: Cambridge University Press, 2017; GINSBURG, Tom. Comparative Constitutional Design. Cambridge: Cambridge University Press, 2012; BEUKERS, Thomas; de WITTE, Bruno; KILPATRICK, Claire. Constitutional Change through Euro-Crisis Law. Cambridge: Cambridge University Press, 2017; ALBERT, Richard; BERNAL, Carlos; BENVINDO, Juliano Zaiden. Constitutional Change and Transformation in Latin America. Oxford: Hart, 2019; CONTIADES, Xenophon. Engineering Constitutional Change: A Comparative Perspective on Europe, Canada and the USA. Abingdon: Routledge, 2013.

6 ALBERT, Richard. Constitutional Amendments: Making, Breaking, and Changing Constitutions. Oxford and New York: Oxford University Press, 2019, p. 61-92.

7 Albert distinguishes between three types of constitutional dismemberment in terms of fundamental rights, basic structure, and constitutional identity. See ALBERT, Richard. Constitutional Amendments: Making, Breaking, and Changing Constitutions. Oxford and New York: Oxford University Press, 2019, p. 85-86.

8 ALBERT, Richard. Constitutional Amendments: Making, Breaking, and Changing Constitutions. Oxford and New York: Oxford University Press, 2019, p. 263-64.

9 ALBERT, Richard. Constitutional Amendments: Making, Breaking, and Changing Constitutions. Oxford and New York: Oxford University Press, 2019, p. 36. 
As Albert's loyal interlocutor, I argue that under the rubric of constitutional dismemberment are two exceptional constitutional phenomena in the real-world constitutional practice: the ought-to-be declared nullity of unconstitutional (formal) constitutional amendments and the legal unity-defying, extraconstitutional (or unconventional) expression of what Hannah Arendt called one of "the most general condition[s] of human existence" - the "natality" in (political) "action."10 Despite Arendt's observation that "startling unexpectedness" inherent in natality underlies political action, ${ }^{11}$ Albert insists that there be no space for an identity-altering constitutional renewal - which results from natality-driven political action - within an existing constitution that makes no distinction between amendment and dismemberment in its provisions governing formal changes. ${ }^{12}$ In such constitutional arrangements, an identity-altering constitutional amendment boils down to a disguised constitutional dismemberment that ought to be nullified, regardless of its political underpinnings. Based on the legalistic stance on what counts as constitutional identity off limits to constitutional amendment, ${ }^{13} \mathrm{Al}-$ bert's foregoing insistence may suck the air out of fundamental constitutional renewal engendered by a rule-challenging, form-resisting political action. As a result, Albert inadvertently reduces constitution-making to the formal enactment of a new codified constitution.

My thesis is that a natality-driven constitutional renewal characteristically defies designed "constitutional form,"14 suggesting that attempts to tame revolutionary constitutional alteration with designed differentiated rules as to formal constitutional change as Albert's theory illustrates are missing the meaning of constitution-making. Even in Albert's designed world of ideal written constitutions wherein processes for identity-altering constitutional change are incorporated, ${ }^{15}$ revolutionary change may result from an unconventional use of such codified processes at the expense of the relevant constitutional rules. Also, the relationship between the real-world constitutions and political action looks even more refracted through Albert's conceptual prism, suggesting the hollowing out of constitutional renewal and the underlying idea of natality. Looked at through the lens of Albert's tripartite classification of constitutional change

\footnotetext{
10 ARENDT, Hannah. The Human Condition. 2. ed. Chicago: University of Chicago Press, 1998, p. 8-9.

11 ARENDT, Hannah. The Human Condition. 2. ed. Chicago: University of Chicago Press, 1998, p. 176-78.

12 ALBERT, Richard. Constitutional Amendments: Making, Breaking, and Changing Constitutions. Oxford and New York: Oxford University Press, 2019, p. 85, 189-90.

13 ALBERT, Richard. Constitutional Amendments: Making, Breaking, and Changing Constitutions. Oxford and New York: Oxford University Press, 2019, p. 84-85.

14 See LOUGHLIN Martin; WALKER, Neil. Introduction. In: LOUGHLIN, Martin; WALKER, Neil. The Paradox of Constitutionalism: Constituent Power and Constitutional Form. Oxford: Oxford University Press, 2007, p. 1-2.

15 As regards the provision for constitutional dismemberment in current national constitutions, Albert mentions Austria, Costa Rica, Spain, and Switzerland. ALBERT, Richard. Constitutional Amendments: Making, Breaking, and Changing Constitutions. Oxford and New York: Oxford University Press, 2019, p. 191-92, 309 n 62.
} 
- amendment, dismemberment, and enactment, some real-world instances of genuine fundamental constitutional renewal are doomed to be condemned for dismembering or otherwise unlawfully altering the existing constitution, while other real-world constitutions that are anything but a function of Arendtian political action are praised for their role in constitutional renewal. My argument unfolds as follows. First, I situate Albert's concept of constitutional dismemberment in the global constitutional landscape and provide a dissection of constitutional dismemberment in light of Arendt's idea of natality, suggesting that not all instances of constitutional dismemberment should be treated as ultra vires amendments that ought to be nullified ex ante or ex post. After unpacking constitutional dismemberment, I then show why Albert's rigid tripartite classification of constitutional change suggests a formalistic approach to constitution-making under which constitutional natality is dismembered. I conclude with remarks on the formalistic turn in comparative constitutional law scholarship as reflected in Constitutional Amendments.

\section{DISMEMBERMENT DISAGGREGATED: CONSTITUTIONAL AMENDMENT ON TRIAL}

As the Indian Supreme Court's German jurisprudence-inspired "basic structure doctrine" continues to migrate to various constitutional realms, scholarship on constitutional amendment has been embedded in a binary aptitude as connoted by the concept of "unconstitutional constitutional amendment". ${ }^{16}$ From the "internal" perspective of the existing constitution, an amendment is either constitutional or unconstitutional, depending on its coherence with the identity of the existing one. ${ }^{17}$ Yet, the question of the identity of a transformative formal constitutional change reveals another binary attitude taking hold in current constitutional scholarship when looked at from outside the existing constitution: it must either continue with the existing constitution or mark a constitutional new beginning. Challenging the prevalent binary propensity in current studies of constitutional change, Albert puts forward the midway concept of constitutional dismemberment with an eye to providing a better and discriminating analytic framework of constitutional change. ${ }^{18}$ Summarily, an identity-altering formal constitutional change does not properly amend a constitution as it deviates from the

16 ROZNAI, Yaniv. Unconstitutional Constitutional Amendments: The Limits of Amendment Powers. Oxford: Oxford University Press, 2017, p 42-69.

17 HARRIS, II, William F. The Interpretable Constitution. Baltimore, MD: Johns Hopkins University Press, 199, p. 176; KUO, Ming-Sung. Reconciling constitutionalism with power: towards a constitutional nomos of political ordering. Ratio Juris, vol. 23, n. 3, Sep./ Nov. 2010, p. 397-98. See also KAHN, Paul W. The Reign of Law: Marbury v. Madison and the Construction of Law. New Haven: Yale University Press, 1997, p. 63-64.

18 Albert considers constitutional dismemberment "the middle ground" that "serves as a bridge between [amendment and a new constitution]." ALBERT, Richard. Constitutional Amendments: Making, Breaking, and Changing Constitutions. Oxford and New York: Oxford University Press, 2019, p. 85. 
latter's existing fundamentals. Nor does it mark a constitutional new beginning in that the continuation of the existing constitution it effectively breaks with is still exhibited in a very visible form. Such identity-altering formal constitutional change dismembers the existing constitution by giving an alternative identity to its remaining form. ${ }^{19}$

It comes as no surprise that Albert's concept of constitutional dismemberment is not the first theoretical endeavour to transcend the binary stance pervading analyses of constitutional change. Prompted by the constantly changing constitutional order in Weimar Germany, scholars such as Georg Jellinek and Carl Schmitt meticulously distinguished between varieties of constitutional change on the conceptual level with an eye to delineating the limits of constitutional amendment. ${ }^{20}$ Unlike the Weimar crisis-prompted theories, Albert's midway concept benefits from decades, if not centuries, of constitutional practices across the globe. Nevertheless, as with Germanophone constitutional theories that were in response to the particular constitutional environment in Weimar, Albert's constitutional dismemberment is situated in the current condition of constitutional change. As noted above, the recognition of unconstitutional constitutional amendments is one of the most important developments in the landscape of comparative constitutional law. ${ }^{21}$ More importantly, the continuing migration of the doctrine of unconstitutional constitutional amendment indicates the increase of transformative and revolutionary constitutional changes in the guise of formal amendments in various constitutional realm and the concomitant judicial response. ${ }^{22}$ The ultimate goal of distinguishing constitutional dismemberment from constitutional amendment is the taming of that increasing constitutional phenomenon.

Albert carves out constitutional dismemberment from constitutional amendment in terms of subject, authority, scope, and purpose. ${ }^{23}$ Among them, scope is the "overriding feature." 24 Aimed at correction, elaboration, reformation, or restoration, ${ }^{25}$

\footnotetext{
19 ALBERT, Richard. Constitutional Amendments: Making, Breaking, and Changing Constitutions. Oxford and New York: Oxford University Press, 2019, p. 68-82.

20 JELLINEK, Georg. Constitutional amendment and constitutional transformation (1906). In: JACOBSON, Arthur J.; SCHLINK, Bernard. Weimar: A Jurisprudence of Crisis. Berkeley: University of California Press, 2000, p. 54-56; SCHMITT, Carl. Constitutional Theory. Translated and edited by Jeffrey Seitzer. Durhnam: Duke University Press, 2007, p. 147-48.

21 See ROZNAI, Yaniv. Unconstitutional Constitutional Amendments: The Limits of Amendment Powers. Oxford: Oxford University Press, 2017, p. 6.

22 For the migration of the doctrine of unconstitutional constitutional amendment, see ROZNAI, Yaniv. Unconstitutional constitutional amendments-the migration and success of a constitutional idea. American Journal of Comparative Law, vol. 61, n. 3, summer, 2013, p. 657-720

23 ALBERT, Richard. Constitutional Amendments: Making, Breaking, and Changing Constitutions. Oxford and New York: Oxford University Press, 2019, p. 79-80.

24 ALBERT, Richard. Constitutional Amendments: Making, Breaking, and Changing Constitutions. Oxford and New York: Oxford University Press, 2019, p. 82.

25 Ibid ALBERT, Richard. Constitutional Amendments: Making, Breaking, and Changing Constitutions. Oxford and New York: Oxford University Press, 2019, p. 80.
} 
an amendment is delimited by "constitutional identity." ${ }^{26}$ In other words, "[a] constitutional amendment entails unbroken unity with the constitution being amended" while "continu[ing]the constitution-making project initiated at the founding or in intervening moments of refounding of the constitution." ${ }^{27}$ In sum, "[a]n amendment is an authoritative change to higher law that corrects, elaborates, reforms, or restores the meaning of the constitution consistent with its existing framework and fundamental presuppositions."28

The way that Albert defines amendment indicates the "formal" character of the distinction he draws between amendment and dismemberment. What distinguishes dismemberment from amendment is that the former breaks "unity" with the existing constitution or alters its "framework" or "fundamental presuppositions" and thereby disrupts the constitution-making project initiated at constitutional (re)founding. Thus, Albert contends that " $\mathrm{t}$ ] he theory of constitutional dismemberment is not rooted in a normative understanding of the constitution."29 The identity of the existing constitution itself decides whether a formal constitutional change is a unity-entailed amendment or an identity-altering dismemberment. This reveals the formalistic element of Albert's theory of constitutional amendment. So does Albert's identification of a new constitution. A new constitution must take the form of a new constitution with the status of higher law enacted outside the replaced constitution. ${ }^{30}$

Yet, a closer look at Albert's "content-based approach" to the distinction between amendment and dismemberment ${ }^{31}$ suggests that Albert is not as formalistic as the foregoing suggests. Constitutional identity that decides whether a formal alteration breaks or preserves the unity of the constitution being altered is not the only object of constitutional dismemberment. "[T]he repeal or replacement of a fundamental right protected by the constitution...that is central to the political community" and a fundamental alteration of the allocation of constitutional powers and other core elements of the central structure of the constitution are also instances of constitutional

\footnotetext{
26 ALBERT, Richard. Constitutional Amendments: Making, Breaking, and Changing Constitutions. Oxford and New York: Oxford University Press, 2019, p. 79.

27 ALBERT, Richard. Constitutional Amendments: Making, Breaking, and Changing Constitutions. Oxford and New York: Oxford University Press, 2019, p. 79.

28 ALBERT, Richard. Constitutional Amendments: Making, Breaking, and Changing Constitutions. Oxford and New York: Oxford University Press, 2019, p. 82 (emphasis added).

29 ALBERT, Richard. Constitutional Amendments: Making, Breaking, and Changing Constitutions. Oxford and New York: Oxford University Press, 2019, p. 84.

30 ALBERT, Richard. Constitutional Amendments: Making, Breaking, and Changing Constitutions. Oxford and New York: Oxford University Press, 2019, p. 76.

31 ALBERT, Richard. Constitutional Amendments: Making, Breaking, and Changing Constitutions. Oxford and New York: Oxford University Press, 2019, p. 78.
} 
dismemberment. ${ }^{32}$ Whether the last two varieties are merely instances of altering constitutional identity is debatable. ${ }^{33}$ Of particular pertinence to my present discussion, however, is the way that a formal change to fundamental rights enshrined in the constitution is considered dismemberment under Albert's theory and what it tells of his theoretical position. Notably, it is repeal or replacement that would render such an alternation constitution-dismembering. ${ }^{34}$ As a corollary, neither enhancement of an existing fundamental right nor addition of a new right to the constitutional bill of rights will dismember the constitution. It is true that they may still be considered constitutional dismemberment for altering constitutional identity in the event. Nevertheless, the asymmetrical stance Albert takes towards the alteration of fundamental rights in identifying instances of constitutional dismemberment reveals the indelible normative characteristic of Albert's theory.

The normative element implicit in the theory of constitutional dismemberment is further evidenced in Albert's attitude towards the doctrine of unconstitutional constitutional amendment. To Albert, those ostensible amendments that have been declared unconstitutional are attempts to "do more than correct, elaborate, reform, or restore the [relevant] constitution[s] within [their] boundaries and presuppositions." ${ }^{\prime 35}$ It is true that such amendments may be declared unconstitutional for reasons other than substantive constitutional norms. Yet, the most interesting cases involving this doctrine exist where an ostensible amendment is declared unconstitutional even if the relevant constitution does not include "the eternity clause" that would render some constitutional provisions unamendable. ${ }^{36}$ In such cases, judicial renderings of unconstitutional constitutional amendment have relied on implicit substantive normative requirements "discovered" and pronounced by the court. ${ }^{37}$ Taken together, unless they are otherwise constitutionalized, formal constitutional alterations that dismember the constitution

32 ALBERT, Richard. Constitutional Amendments: Making, Breaking, and Changing Constitutions. Oxford and New York: Oxford University Press, 2019, p. 85.

33 See POLZIN, Monika. Constitutional identity, unconstitutional amendments and the idea of constituent power: the development of the doctrine of constitutional identity in German constitutional law. International Journal of Constitutional Law, vol. 14, n. 2, Apr./Jun. 2016, p. 411-38.

34 ALBERT, Richard. Constitutional Amendments: Making, Breaking, and Changing Constitutions. Oxford and New York: Oxford University Press, 2019, p. 85.

35 ALBERT, Richard. Constitutional Amendments: Making, Breaking, and Changing Constitutions. Oxford and New York: Oxford University Press, 2019, p. 218.

36 See, e.g., BARANGER, Denis. The language of eternity: judicial review of the amending power in France (or the absence thereof). Israel Law Review, vol. 44, n. 3, Nov./Feb. 2011-12, p. 389-428; PREUSS, Ulrich K. The implications of "eternity clauses": the German experience.' Israel Law Review, vol. 44, n. 3, Nov./Feb. 2011-12, p. 429-88.

37 ALBERT, Richard. Constitutional Amendments: Making, Breaking, and Changing Constitutions. Oxford and New York: Oxford University Press, 2019, p. 149-58. Yaniv Roznai further identifies what he calls "supra-constitutional" limits derived from natural law and international law. Notably, natural law-based supra-constitutional limits are also discovered and pronounced by the court. ROZNAI, Yaniv. Unconstitutional Constitutional Amendments: The Limits of Amendment Powers. Oxford: Oxford University Press, 2017, p. 71-102. 
fall in the category of unconstitutional constitutional amendments to be nullified by the court ex ante or ex post either for their breaking the unity of the constitution or infringing fundamental substantive normative principles, suggesting a legalistic view of transformative and revolutionary constitutional change. ${ }^{38}$

Through the lens of Albert's theory of constitutional dismemberment, the transformative and revolutionary character of formal constitutional changes lies in their high impact on the existing constitution, regardless of the politico-sociological forces underpinning such changes. ${ }^{39}$ Yet, Albert's advocacy for the constitutionalization of constitutional dismemberment by differentiating amendment rules in constitutional design seems to suggest otherwise. Notably, both Albert's theory of constitutional dismemberment and his proposal for its codification in constitutional design are intended to tame transformative and revolutionary constitutional change by means of legal continuity. ${ }^{40}$ Nevertheless, legal continuity, or rather, legal framing, is not sufficient for the constitutionalization of dismemberment. Rather, Albert suggests that a higher degree of "popular consent" is required of constitutional dismemberment than of constitutional amendment. Thus, in his designed world of ideal written constitutions, the rules for formal constitutional change must be differentiated, requiring a higher threshold of agreement for transformative and revolutionary changes, i.e., constitutional dismemberments. ${ }^{41}$

Linking formal constitutional change to democracy, Albert blends his formalistic suggestions with substantive value. ${ }^{42}$ Seen in this light, he is not indifferent to the politico-sociological foundation of transformative and revolutionary constitutional change. Even so, conformity with the rules as codified in the written constitution takes precedence over political legitimacy. The constitution making no distinction between constitutional dismemberment and constitutional amendment in its current design, a transformative or revolutionary formal constitutional alteration thereof amounts to constitutional nullity as it is in essence an unconstitutional constitutional amendment. ${ }^{43}$

38 ALBERT, Richard. Constitutional Amendments: Making, Breaking, and Changing Constitutions. Oxford and New York: Oxford University Press, 2019, p. 218.

39 This echoes Gary Jacobsohn's view on constitutional revolution. See JACOBSOHN, Gary Jeffrey. Theorizing the constitutional revolution. Journal of Law and Courts, vol. 2, n.1, Spring 2014, p. 1-32..

40 ALBERT, Richard. Constitutional Amendments: Making, Breaking, and Changing Constitutions. Oxford and New York: Oxford University Press, 2019, p. 189-94.

41 ALBERT, Richard. Constitutional Amendments: Making, Breaking, and Changing Constitutions. Oxford and New York: Oxford University Press, 2019, p. 190, 263-64.

42 ALBERT, Richard. Constitutional Amendments: Making, Breaking, and Changing Constitutions. Oxford and New York: Oxford University Press, 2019, p. 268-70. For democracy in and of itself as a substantive value, see BRETTSCHNEIDER, Corey. The value theory of democracy. Politics, Philosophy \& Economics, vol. 5, n. 3, Oct./Jan. 2006-07, p. 259-78. Cf. TRIBE, Laurence H. The puzzling persistence of process-based constitutional theories. Yale Law Journal, vol. 89, n. 6, 1980, p. 1067-72.

43 While Albert does not take issue with the boundary of constitutional amendment as delimited in the comparative jurisprudence on unconstitutional constitutional amendments, he falls short of endorsing the judicial 
The question is whether such a legalistic understanding of revolutionary constitutional change adequately captures the meaning of revolution in the political project of constitutional governance. To answer this question, we need to ask what constitution-making is really about.

With the idea of "new beginning" brought to the fore in her On Revolution, Aren$\mathrm{dt}$ shed illuminating light on the question of constitution-making at the core of constitutional theory. ${ }^{44}$ Constitution-making marks a new beginning by concluding the revolution with the foundation of freedom. It is such a new beginning characteristic of the foundation of freedom, not the new constitution in writing, that gives meaning to the act of constitution-making. ${ }^{45}$ Thus, constitution-making that sets a constitutional project in motion is inseparable from the quest for political freedom. According to Arendt, political freedom lies at the core of one of the "three fundamental human activities:... action." ${ }^{46}$ Notably, among "the most general condition[s] of human existence" with which "action has the closest connection" is "natality." 47 Elucidating how natality bears on the freedom-oriented political action, Arendt remarked,

"[T]he new beginning inherent in birth can make itself felt in the world only because the newcomer possesses the capacity of beginning something anew, that is, of acting. In this sense of initiative, an element of action, and therefore natality is inherent in all human activities." $^{\prime 48}$

Being the fountainhead of actions of political freedom, natality thus underlies the meaning of revolution in the political project of constitutional governance. Sowing the seeds of a new beginning with its inherent "startling unexpectedness," natality

invalidation of unconstitutional constitutional amendments for reasons of democracy. See ALBERT, Richard. Constitutional Amendments: Making, Breaking, and Changing Constitutions. Oxford and New York: Oxford University Press, 2019, p. 217-23. Seen in this light, he does not quite treat an unconstitutional constitutional amendment as an act of constitutional nullity. Yet, his suggestions for an ex ante judicial guardianship of the boundary of constitutional amendment in the pre-ratification stage envisage judicial prevention of constitutional nullity in respect of formal constitutional alterations. ALBERT, Richard. Constitutional Amendments: Making, Breaking, and Changing Constitutions. Oxford and New York: Oxford University Press, 2019, p. $223-27$.

44 ARENDT, Hannah. On Revolution. Rep. ed. New York: Penguin, 1990, p. 20-47.

45 ARENDT, Hannah. On Revolution. Rep. ed. New York: Penguin, 1990, p. 144-45. See also PREUSS, Ulrich K. Constitutional Revolution: The Link between Constitutionalism and Progress. Translated by Deborah Lucas Schneider. Atlantic Highlands, NJ: Humanities Press, 1995, p. 25-37, 110.

46 See ARENDT, Hannah. On Revolution. Rep. ed. New York: Penguin, 1990, p. 30-31, 233-36; ARENDT, Hannah. On Revolution. Rep. ed. New York: Penguin, 1990, p. 149-76.

47 ARENDT, Hannah. On Revolution. Rep. ed. New York: Penguin, 1990, p. 8-9.

48 ARENDT, Hannah. On Revolution. Rep. ed. New York: Penguin, 1990, p. 9. 
further clothed political action in an aura of "miracle."49 Natality puts political action pursuing freedom in tension with rules and forms. ${ }^{50}$

Through the lens of natality, a revolutionary constitutional change looks very different from what Albert has said of constitutional dismemberment. Imagine the following two scenarios under a constitution that provides for an undifferentiated amendment rule. In the first is a formal constitutional change that alters constitutional identity in full conformity with the unitary amendment rule but does not really result from deliberation and reflection among members of the political community. From the perspective of Albert's theory, such a change is a straightforward instance of constitutional dismemberment. Through the lens of natality, it is far from the result of revolutionary action of political freedom. Obviously it cannot claim democratic legitimacy required of such a grand-scale constitutional alteration. Nor can it be deemed as the culmination of a natality-driven political action. Thus, subjecting the imaginary formal constitutional change to judicial nullification ex ante or ex post as an ultra vires constitutional amendment does not contradict the meaning of revolution in the political project of constitutional governance.

Alternatively, the same grand-scale constitutional alteration does command genuine popular support as a result of a robust democratic process and cross the same supermajority threshold required of an amendment unquestionably as in the first scenario. In stark contrast to the ought-to-be-nullified amendment in the first scenario, the second imaginary constitutional alteration is undoubtedly a function of natality. Yet, through the lens of Albert, these two imaginary formal constitutional alterations are no different. As in the first scenario, the natality-bred constitutional alteration here is subject to ex ante or ex post judicial nullification, too. After all, it breaks the unity of the imaginary constitution. Taken together, Albert's theory of constitutional dismemberment not only captures those unfounded attempts to dismember the existing constitution under the pretence of a constitutional new beginning but also extends to cases of constitutional natality. With revolution recast in legalistic terms, Albert seems to embank the underlying human condition of revolutionary politics - natality. Inside the embankment of a unitary amendment rule is no place for the stream of constitutional natality. Can natality really be tamed by such constitutional embankment?

Notably, natality-driven political action materializes in the process of constitution-making before it translates into the enacting of a codified constitution. ${ }^{51}$ Thus,

49 ARENDT, Hannah. On Revolution. Rep. ed. New York: Penguin, 1990, p. 177, 246-47.

50 See KAHN, Paul W. The Reign of Law: Marbury v. Madison and the Construction of Law. New Haven: Yale University Press, 1997, p. 54-59, 64-69. This translates into the modern concept of constituent power in constitutional theory. See LOUGHLIN, Martin. The concept of constituent power. European Journal of Political Theory, vol. 13, n. 2, Apr./Jun. 2014, p 231-34.

51 ARENDT, Hannah. On Revolution. Rep. ed. New York: Penguin, 1990, p. 141-45. 
in the foregoing second scenario, constitutional natality has already burst before the existing constitution is actually altered. To be precise, it is the lead-up political action, not the constitution-dismembering formal change, that breaks the unity of the existing constitution. In other words, the old constitutional identity has already been altered in the process of political action and counteraction. The eventual change to the constitutional document coming out of the existing amendment rule is merely the end result of constitutional identity-altering political action, not the cause of the breakdown of constitutional identity. In such a scenario, denying the resulting constitutional change the character of constitutional new beginning is far from the preservation of constitutional identity. Rather, condemning it as an unlawful constitutional dismemberment (or rather, an unconstitutional constitutional amendment) shows an intransigent attempt to restore the ousted identity, despite the new one to which natality has given rise.

\section{WHEN CONSTITUTION-MAKING BECOMES CONSTITUTION- -WRITING: CONSTITUTIONAL NATALITY DISMEMBERED}

Despite no place for identity-altering formal change to the constitution that does not provide for rules governing such changes, Albert does allow for constitutional new beginning in his theory of constitutional change. Addressing reformers who are acting to "make a lawful change of the larger magnitude" that exceeds the boundary of constitutional amendment in the majority of the real-word constitutions in which only a unitary undifferentiated rule is provided for constitutional amendment, Albert points them in the direction of "mak[ing] a new constitution." ${ }^{52}$ Notably, the constitution whose creation constitutional reformers would "invest time and resources [in with] nontrivial risks of failure [incurred]" has to be new not only in substance but also in form: it is a constitution with new authorship, new name, and new substance, breaking "legal continuity" with that which it is intended to reform. ${ }^{53}$ Thus, what sets such constitution-making apart from the imaginary natality-driven constitutional alteration as discussed in Section II is not whether the latter requires time and resources or not. Nor does the foregoing imaginary natality-driven constitutional alteration necessarily incur less risks of failure. On the contrary, as will be further discussed, the underlying political action may well face more cumbersome challenges in the imaginary scenario, especially when the undifferentiated amendment rule requires an exceedingly high threshold of

\footnotetext{
52 ALBERT, Richard. Constitutional Amendments: Making, Breaking, and Changing Constitutions. Oxford and New York: Oxford University Press, 2019, p. 189 (emphasis added).

53 For the role of authorship in constitutional theory, see KUO, Ming-Sung. Cutting the Gordian knot of legitimacy theory? an anatomy of Frank Michelman's presentist critique of constitutional authorship. International Journal of Constitutional Law, vol. 7, n. 4, Oct./Dec. 2009, p 683-714.
} 
popular consent, ${ }^{54}$ than the making of a new constitution as envisaged in Albert's theory. As a whole, the creation of a new constitutional text is characteristic of Albert's version of constitutional new beginning.

In line with the formalistic view on constitutional new beginning, Albert proposes that reformers differentiate constitutional rules in terms of three types of formal constitutional change in their constitutional design: "rules changeable by amendment, rules changeable by dismemberment, and unamendable rules changeable only by creating a new constitution." ${ }^{55}$ The first two are to be explicitly stipulated in the design of constitutional rules on formal constitutional alteration, while the last - the repeal or replacement of the unamendable rules by constitutional enactment - is a requirement by necessary implication. From Albert's calibration of the threshold of popular consent required of formal constitutional changes to their degree of impact on the existing constitution, it must be inferred that the threshold for dismemberment needs to reflect its transformative and revolutionary character and is thus set higher than that for amendment. And, this exposes the limitation of the formalistic conceptualization of constitutional new beginning as reflected in Albert's tripartite classification of constitutional changes: amendment, dismemberment, and enactment.

Suppose that an ideal codified constitution differentiates amendment and dismemberment with a provision defining state territory enshrined as the unamendable rule as observes Albert's advice. ${ }^{56}$ For an amendment, it provides that an amendment require the agreement of at least two thirds of the total members of the unicameral parliament followed by popular consent with more than one-half of the valid ballots cast in favour in a popular referendum. For such a referendum to be valid, the voting rate must exceed one-half of the eligible electors. Given the transformative and revolutionary impact of altering suffrage on the constitutional order, the imaginary constitution treats any change on suffrage as dismemberment, requiring the agreement of at least three quarters of the total members of the unicameral parliament followed by a referendum. It requires the number of valid votes in favour exceeding one-half of the total number of eligible electors to sanction a dismemberment bill passed by the parliament. ${ }^{57}$

\footnotetext{
54 Apparently this may result in an instance of what Albert calls "constructive unamendability." ALBERT, Richard. Constitutional Amendments: Making, Breaking, and Changing Constitutions. Oxford and New York: Oxford University Press, 2019, p. 158-59.

55 ALBERT, Richard. Constitutional Amendments: Making, Breaking, and Changing Constitutions. Oxford and New York: Oxford University Press, 2019, p. 264.

56 The following thought experiment is designed in light of actual constitutional politics in Taiwan.

57 This imaginary constitutional design is an adaptation of the amendment rule of the ROC Constitution, which is the working constitution of Taiwan. Additional Article 12 provides: "Amendment of the Constitution shall be initiated upon the proposal of one-fourth of the total members of the Legislative Yuan, passed by at least three-fourths of the members present at a meeting attended by at least three-fourths of the total members of the Legislative Yuan, and sanctioned by electors in the free area of the Republic of China at a referendum held upon expiration of a six-month period of public announcement of the proposal, wherein the
} 
At first glance, the three-tiered design of constitutional change seems to be ideal. Upon close examination, however, this model design cannot escape the startling unexpectedness posed by constitutional natality. To see why it is so, let us imagine the following two scenarios under this imaginary designed constitution.

In the first scenario is a reform proposal to extend suffrage to citizens over the age of eighteen but under the age of twenty. Enthusiastically pushed by grassroots organizations, this proposal easily passes the high threshold at the parliamentary stage, with an overwhelming cross-party support. ${ }^{58}$ Yet, despite the passionate campaign and the general support as indicated in serial polls, it eventually falls short in the referendum stage. With $70 \%$ of eligible voters casting their ballots and $70 \%$ of the ballots cast in favour, this reform only gains the support of $49 \%$ of eligible voters short of the required one-half threshold, ending up as a failed attempt at constitutional dismemberment. Through Albert's lens, this reform is defeated. Let us suppose that following the referendum, the parliament further adopts a unanimous resolution instructing the president to promulgate the reform proposal as a valid formal change to the constitution on grounds that the reform bill is essentially a constitutional amendment without regard to dismemberment. Through Albert's lens again, this would amount to an unlawful constitutional coup. Yet, when looked at through Arendt's lens of natality, this would evoke a constitutional new beginning. Specifically, the constitutional order changes with its democratic foundation reimagined in a genuinely democratic fashion by virtue of an exercise of what Bruce Ackerman and Neal Katyal calls "unconventionality."59 Condemning it as an unlawful constitutional coup or an unconstitutional constitutional alteration would mean a betrayal of the meaning of constitutional renewal - to mark a new beginning of constitutional life.

To be sure, it may be countered that reformers should opt for constitutional enactment instead of going down the foregoing route of unconventional application, if not intentional manipulation, of the enshrined rules on constitutional change. Embarking on the time-consuming and resources-demanding route of constitutional enactment is the right way forward as it would keep the proposed reform on the track of lawfulness without contravening the rules set out in the imaginary constitution. ${ }^{60}$

number of valid votes in favor exceeds one-half of the total number of electors. The provisions of Article 174 of the Constitution shall not apply." For a helpful introduction to the Taiwan constitution, see YEH, Jiunn-rong. The Constitution of Taiwan: A Contextual Analysis. Oxford: Hart, 2016.

58 This is an adaptation of an ongoing development in Taiwan. See TAIWAN likely to pass constitutional amendment lowering voting age to 18. Taiwan News, 19 Feb 2020. Available in: <https://www.taiwannews. com.tw/en/news/3878403>. Last visited: 04/04/2020.

59 Unconventionality in formal constitutional change results from deviation from the constitution rules on amendment but without totally disregarding them. See ACKERMAN Bruce; KATYAL, Neal. Our unconventional founding. University of Chicago Law Review, vol. 62, n. 2, Spring 1995, p. 558-59.

60 ALBERT, Richard. Constitutional Amendments: Making, Breaking, and Changing Constitutions. Oxford and New York: Oxford University Press, 2019, p. 189. 
This rejoinder raises two fundamental issues here. First, it is unclear what it means to be lawful to step out of the existing constitutional framework followed by the enactment of a new constitution. After all, a new constitution is a creation ex nihilo from the legal perspective ${ }^{61}$ unless some sort of natural law is invoked as the higher law delimiting the boundary of constitutional enactment. ${ }^{62}$ Thus, lawfulness in the rejoinder does not so much concern the legality of the proposed reform itself as focuses on assuring that the rules on formal constitutional change in the imaginary constitution be complied with to the letter. The rule of law project Albert persuasively links to written constitutions is manifested in the impeccable adherence to the rules on formal constitutional change. ${ }^{63}$ This brings up the second issue.

The main reason underlying Albert's proposal to codify identity-altering dismemberment alongside amendment in constitutional design is to contain, or rather co-opt, transformative and revolutionary changes by means of constitutional incorporation. In this way, Albert argues, constitutions can change, piecemeal or on a grand scale, within a given institutional framework without breaking legal continuity. ${ }^{64}$ Viewed thus, enabling ordered constitutional transformation or revolution within a continuing constitutional framework is the end, while conformity with the rules set out in the constitutional order is the means. Yet, with legal continuity in the context of constitutional change conditioned on the impeccable adherence to the rules governing formal constitutional changes, the unconventional reform change in the first scenario would be banished from the imaginary constitutional framework to the uncharted legal territory of constitutional creation ex nihilo. To put it differently, even if an ordered but unconventional constitutional transformation as illustrated in the foregoing reform proposal has taken place, its constitutional status remains contingent on the legalistic decision as to whether it has been in conformity with the codified rules on constitutional amendment and dismemberment in the imaginary constitution. Breaking the "law" of constitutional change in the imaginary constitution, it comes down to constitutional nullity. In sum,

61 FRIED, Charles. The Supreme Court, 1994 Term - foreword: revolutions?. Harvard Law Review, vol. 109, n. 1, Nov. 1995, p. 18.

62 The German Federal Constitutional Court alluded to the possibility of the original constitutional provisions being unlawful in the Southwest Case ((1951) I BverfGE 225). See ROZNAI, Yaniv. Unconstitutional Constitutional Amendments: The Limits of Amendment Powers. Oxford: Oxford University Press, 2017, p. 76. Notably, a constitutional creation ex nihilo does not mean constitutional chaos. LOUGHLIN, Martin. The concept of constituent power. European Journal of Political Theory, vol. 13, n. 2, Apr./Jun. 2014, p. 229. See also MICHELMAN, Frank I. Always Under Law. Constitutional Commentary, vol. 12, n. 2, Summer 1995, p. 227-47. Yet, it is one thing to say that it is orderly; it is another to say that it is lawful in the same sense as a lawful constitutional amendment or dismemberment. Lawfulness in the latter presupposes some pre-existing legal criteria, which is not contemptible with the idea of creation ex nihilo.

63 ALBERT, Richard. Constitutional Amendments: Making, Breaking, and Changing Constitutions. Oxford and New York: Oxford University Press, 2019, p. 269-71.

64 ALBERT, Richard. Constitutional Amendments: Making, Breaking, and Changing Constitutions. Oxford and New York: Oxford University Press, 2019, p. 188-94, 263-64, 268-69. 
Albert's emphasis on the importance of legal continuity in constitutional renewal is not so much about institutional continuity that channels constitutional transformation in an orderly way as about compliance with the rules on formal constitutional change. The means becomes the end.

The foregoing scenario indicates that the functioning of legal continuity in taming transformative and revolutionary constitutional alteration relies not only on conformity with the rules but also on the continuation of the institutional framework. What is missing from the tripartite classification of constitutional change is the recognition that the constitutional form of legal continuity will have to face the rule-challenging popular quest for constitutional renewal. ${ }^{65}$ Failing to appreciate this real-world constitutional phenomenon, insistence on conformity with the codified dismemberment rule may unexpectedly pit legal continuity against the taming of transformative and revolutionary constitutional change as illustrated in the first scenario. Nevertheless, Albert's proposed design on the rules governing formal constitutional change may be otherwise defended in the following line: a transformative or revolutionary constitutional change must show its seriousness by going through the arduous process of creating a constitution ex nihilo as alluded to in the differentiation of amendment, dismemberment, and enactment. How far this line of argument can go will transpire in light of the second scenario of constitutional reform.

Suppose that the government has exercised effective control only over a frontier island province of the entire state territory defined in the imaginary constitution over the past seven decades. Numerous polls also constantly indicate that over three-quarters of the people support the idea to redefine state territory in the constitution to close the gap between political reality and constitutional definition. As indicated above, the provision for state territory is codified as an unamendable rule in the imaginary constitution. Looked at through Albert's lens, the only "lawful" way to redefine state territory in constitutional terms is down the failure-prone, time-consuming, and resources-demanding route of constitutional creation ex nihilo. But is the route of enactment really more arduous than that of amendment, not to mention dismemberment?

Imagine that, in order to adopt a new constitution with state territory redefined in line with the islands under the government effective control, the reformers follow Albert's advice and convene a constituent assembly with all societal sectors fully represented. Yet, although the change on state territory commands robust popular support

65 ALBERT, Richard. Constitutional Amendments: Making, Breaking, and Changing Constitutions. Oxford and New York: Oxford University Press, 2019, p. 268-69. Emmanuel Joseph Sieyès made this point of revolutionary constitution-making in the context of the French Revolution. SIEYĖS, Emmanuel Joseph. What Is the Third Estate? Translated by M. Blondel. London: Pall Mall Press, 1963, p. 127-28. See also KAHN, Paul W. The Reign of Law: Marbury v. Madison and the Construction of Law. New Haven: Yale University Press, 1997, p. 6974; LOUGHLIN, Martin. The concept of constituent power. European Journal of Political Theory, vol. 13, n. 2, Apr./Jun. 2014, p. 227, 231-32. 
and has been the impetus for this imaginary effort of constitutional renewal, public opinion is divided over other issues that need to be stipulated in a constitution such as whether the office of presidency should be ceremonial or executive. Even so, the constituent assembly adopts a new constitution with the support of two-thirds of the total delegates and subjects it to a referendum for popular approval. With $75 \%$ of eligible voters taking part in the referendum, the proposed new constitution is approved with $55 \%$ of total ballots cast in favour of its adoption. From the perspective of democracy, this imaginary new constitution has fairly popular support, marking a legitimate constitutional new beginning. Nevertheless, compared to the reform proposal to extend suffrage in the first scenario, this constitutional enactment is less cumbersome than dismemberment as well as amendment. With the benefit of institutional continuity deprived, this exercise of constitutional creation ex nihilo is prone to more risks. Under the differentiated rules on formal constitutional change modelled after Albert's proposed constitutional design, the most transformative and revolutionary constitutional alteration can be less time-consuming and resources-demanding than its lesser variety but remains equally risky.

Taken together, the foregoing two scenarios of constitutional reform suggest that compartmentalization of constitutional changes in constitutional design with constitutional new beginning consigned to the extraconstitutional route of enactment can stand in the way of genuine constitutional renewal. It may even contradict the goal of taming transformative and revolutionary constitutional changes with the institutional constraints of legal continuity. To make things more complicated, if a new constitution is simply promulgated with the ostensible democratic support expressed in a plebiscite-like popular vote, it would be fair to assume that this creation ex nihilo would still qualify as a constitutional new beginning under Albert's tripartite classification of constitutional changes. In this way, the writing of a new constitution marks the most revolutionary and radical form of constitutional change and the beginning of a novel constitutional order, thereby hollowing out the meaning of constitution-making.

As Arendt perceptively observed nearly sixty years ago, constitution-making is not only about the making of law. It is also a political act that "constitutes" the political order and the people. ${ }^{66}$ Constitution-making is constitutive because it is engendered by political action that is powered by one of the general conditions of human existence - natality. As the foregoing imaginary constitutional order shows, Albert's designed world of ideal written constitutions assumes an orderly expression of desires for constitutional reform. They are expected to find their place in the respective designated

66 See ARENDT, Hannah. On Revolution. Rep. ed. New York: Penguin, 1990, p. 145; PREUSS, Ulrich K. Constitutional Revolution: The Link between Constitutionalism and Progress. Translated by Deborah Lucas Schneider. Atlantic Highlands, NJ: Humanities Press, 1995, p. 109-10. Cf. ROSENFELD, Michel. The Identity of the Constitutional Subject: Selfhood, Citizenship, Culture, and Community. Abingdon: Routledge, 2009. 
constitutional channels. Yet, this is not the way that the world of politics operates. Rather, politics always plays out in a way startling its observers, defying existing frameworks, and continuing to bother institutional designers. ${ }^{67}$ Against this backdrop and through the lens of Albert's constitutional design, an Arendtian constitution-making may well be either condemned as unlawful within an Albertine constitution or banished to an exercise of constitution-writing from without. While an Albertine constitution only envisages a dismembered constitutional natality that is tameable by constitutional design, the meaning of constitutional renewal is hollowed out with constitution-writing taking the place of constitution-making in Constitutional Amendments. ${ }^{68}$

\section{IN LIEU OF CONCLUSION: CONSTITUTION-MAKING IS MORE THAN CONSTITUTIONAL DESIGN}

Once left on the margin of the landscape of comparative law, constitutions have recently generated great interest from comparatists. ${ }^{69}$ To be more precise, not only constitutions themselves but also constitutional phenomena become objects of comparative constitutional studies. How they are interpreted by judges, how they are applied by politicians, how robust their protection of fundamental right is, how state powers are organized and allocated in constitutional terms, and so on all appear in various venues, including monograph series and specialized journals. Constitutional change and constitutional design are no exception. With his encyclopaedic knowledge of comparative constitutional amendments, Albert has helped us to see the nuances of formal constitutional alterations more clearly with his tremendous "Constitutional Amendments" and theoretical discovery - the concept of constitutional dismemberment.

I have shown that drawing upon comparative constitutions, Albert not only provides us constitutional scholars with a more sophisticated analytic framework of constitutional change but also pitches constitutional practitioners in the design of rules on constitutional change with his concept of constitutional dismemberment among other

\footnotetext{
67 KAHN, Paul W. The Reign of Law: Marbury v. Madison and the Construction of Law. New Haven: Yale University Press, 1997, p. 64-74; LOUGHLIN, Martin. The concept of constituent power. European Journal of Political Theory, vol. 13, n. 2, Apr./Jun. 2014, p. 231-34. Conscious of the political character of the constitutional project, Albert nonetheless envisages a tamed political world. See ALBERT, Richard. Constitutional Amendments: Making, Breaking, and Changing Constitutions. Oxford and New York: Oxford University Press, 2019, p. 269.

68 Albert notes constitution as an action through which consent is renewed and the constitutional order is continually re-legitimated. Nevertheless, he only allows for such action within the limits of the designed rules on constitutional change. ALBERT, Richard. Constitutional Amendments: Making, Breaking, and Changing Constitutions. Oxford and New York: Oxford University Press, 2019, p. 195-96.

69 Compare, TWINING, William. Globalisation and Legal Scholarship. Nijmegen: Wolf Legal Publishers, 2011, p. 21, with HIRSCHL, Ran. Comparative Matters: The Renaissance of Comparative Constitutional Law. Oxford and New York: Oxford University Press, 2014, p. 77-78.
} 
comparative insights. ${ }^{70}$ This is an exemplar of joining theory and practice. Yet, with Albert's role moving from constitutional comparatist to constitutional practice and design adviser, constitutional dismemberment raises more questions than answers. Applying constitutional dismemberment to real-world constitutions that provide for only a set of unitary undifferentiated rules on formal constitutional changes, it may still fall under the spell of the doctrine of unconstitutional constitutional amendment. With all identity-altering constitutional changes under such constitutions condemned as unlawful constitutional dismemberments (or rather unconstitutional constitutional amendments), constitutional changes that would give rise to new meaning and identity resulting from natality-powered political action are turned into constitutional nullity. Moreover, when translated into constitutional design, the concept of constitutional dismemberment and the concomitant tripartite classification of constitutional changes - amendment, dismemberment, and enactment - will likely fall short of taming transformative and revolutionary constitutional alternations. Politics that gives meaning to the constitution characteristically defies predetermined rules and challenges designed forms. ${ }^{71}$ Failing to appreciate the free flow of natality Arendt perceptively identified in the condition of human existence, a scientific, theory-based design on constitutional change of Albert's sophisticated kind mistakes constitution-writing and constitutional design for constitution-making, hollowing out the meaning of constitutional renewal.

The foregoing observation does not mean that constitutional design is not important to constitution-making. Nor does it suggest that constitutional design needs no theoretical guidance or comparative insight. Yet, to do justice to the constitutional project, we must take the phenomenon of constitution-making and its concomitant real-world politics seriously. As with many fellow travellers in comparative constitutional studies, Albert focuses on comparative written constitutions rather than comparative constitutional phenomena. ${ }^{72}$ The writing of constitutional codes stands front and center, eclipsing the big picture of intricate constitutional phenomena relating to the making of a constitutional order. As a result, "written constitutionalism" steers the theory, which is further applied to defend the former. ${ }^{73}$ By transcending the fascination

70 ALBERT, Richard. Constitutional Amendments: Making, Breaking, and Changing Constitutions. Oxford and New York: Oxford University Press, 2019, p. 229-60.

71 KAHN, Paul W. The Reign of Law: Marbury v. Madison and the Construction of Law. New Haven: Yale University Press, 1997, p. 69-74; LOUGHLIN, Martin. The concept of constituent power. European Journal of Political Theory, vol. 13, n. 2, Apr./Jun. 2014, p. 231-32. See also KAHN, Paul W. Political Theology: Four New Chapters on the Concept of Sovereignty. New York: Columbia University Press, 2012.

72 KUO, Ming-Sung. A dubious Montesquieuian moment in constitutional scholarship: reading the empirical turn in comparative constitutional law in the light of William Twining and his hero. Transnational Legal Theory, vol. 4, n. 4, 2013, p. 491-93.

$73 \mathrm{KUO}$, Ming-Sung. A dubious Montesquieuian moment in constitutional scholarship: reading the empirical turn in comparative constitutional law in the light of William Twining and his hero. Transnational Legal Theory, vol. 4, n. 4, 2013, p. 493-501. 
with well-styled constitutions and bringing unwieldy, flowing constitutional natality to the attention of comparatists, ${ }^{74}$ Albert will enrich general theory of constitutional change even more with his landmark contribution of Constitutional Amendments.

\section{REFERENCES}

ACKERMAN, Bruce. We the People. vols. 1-3. Cambridge: Belknap, 1991-2014.

ACKERMAN, Bruce. Revolutionary Constitutions: Charismatic Leadership and the Rule of Law. Cambridge: Belknap, 2019.

ACKERMAN Bruce; KATYAL, Neal. Our unconventional founding. University of Chicago Law Review, vol. 62, n. 2, p. 475-573, Spring 1995.

ALBERT, Richard. Constitutional Amendments: Making, Breaking, and Changing Constitutions. Oxford and New York: Oxford University Press, 2019.

ALBERT, Richard; BERNAL, Carlos; BENVINDO, Juliano Zaiden. Constitutional Change and Transformation in Latin America. Oxford: Hart, 2019.

ARATO, Andrew. Civil Society, Constitution, and Legitimacy. Lanham: Rowman \& Littlefield, 2000.

ARATO, Andrew. Post Sovereign Constitution Making: Learning and Legitimacy. Oxford and New York: Oxford University Press, 2016.

ARATO, Andrew. The Adventures of the Constituent Power: Beyond Revolutions? Cambridge: Cambridge University Press, 2017.

ARENDT, Hannah. On Revolution. Rep. ed. New York: Penguin, 1990.

ARENDT, Hannah. The Human Condition. 2. ed. Chicago, IL: University of Chicago Press, 1998.

BARANGER, Denis. The language of eternity: judicial review of the amending power in France (or the absence thereof). Israel Law Review, vol. 44, n. 3, p. 389-428, Nov./Feb. 2011-12.

BEUKERS, Thomas; de WITTE, Bruno; KILPATRICK, Claire. Constitutional Change through Euro-Crisis Law. Cambridge: Cambridge University Press, 2017.

BRETTSCHNEIDER, Corey. The value theory of democracy. Politics, Philosophy \& Economics, vol. 5, n. 3, p. 259-78, Oct./Jan. 2006-07.

CONTIADES, Xenophon. Engineering Constitutional Change: A Comparative Perspective on Europe, Canada and the USA. Abingdon: Routledge, 2013.

74 Ackerman's recent comparative study of "constitutional pathways" is a good example. See ACKERMAN, Bruce. Revolutionary Constitutions: Charismatic Leadership and the Rule of Law. Cambridge, MA: Belknap, 2019. 
FRIED, Charles. The Supreme Court, 1994 Term - foreword: revolutions?. Harvard Law Review, vol. 109, n. 1, p. 13-77, Nov. 1995.

GINSBURG, Tom. Comparative Constitutional Design. Cambridge: Cambridge University Press, 2012.

HARRIS, II, William F. The Interpretable Constitution. Baltimore: Johns Hopkins University Press, 1993.

HIRSCHL, Ran. Comparative Matters: The Renaissance of Comparative Constitutional Law. Oxford and New York: Oxford University Press, 2014.

JACOBSOHN, Gary Jeffrey. Theorizing the constitutional revolution. Journal of Law and Courts, vol. 2, n.1, p. 1-32, Spring 2014.

JELLINEK, Georg. Constitutional amendment and constitutional transformation (1906). In: JACOBSON, Arthur J.; SCHLINK, Bernard. Weimar: A Jurisprudence of Crisis. Berkeley: University of California Press, 2000. p. 54-56.

KAHN, Paul W. The Reign of Law: Marbury v. Madison and the Construction of Law. New Haven: Yale University Press, 1997.

KAHN, Paul W. Political Theology: Four New Chapters on the Concept of Sovereignty. New York: Columbia University Press, 2012.

KUO, Ming-Sung. Cutting the Gordian knot of legitimacy theory? an anatomy of Frank Michelman's presentist critique of constitutional authorship. International Journal of Constitutional Law, vol. 7, n. 4, p 683-714, Oct./Dec. 2009.

KUO, Ming-Sung. Reconciling constitutionalism with power: towards a constitutional nomos of political ordering. Ratio Juris, vol. 23, n. 3, p. 390-410, Sep./ Nov. 2010.

KUO, Ming-Sung. A dubious Montesquieuian moment in constitutional scholarship: reading the empirical turn in comparative constitutional law in the light of William Twining and his hero. Transnational Legal Theory, vol. 4, n. 4, p.487-501, 2013.

LOUGHLIN, Martin. The concept of constituent power. European Journal of Political Theory, vol. 13, n. 2, p. 218-37, Apr./Jun. 2014.

LOUGHLIN, Martin; WALKER, Neil. Introduction. In: LOUGHLIN, Martin; WALKER, Neil. The Paradox of Constitutionalism: Constituent Power and Constitutional Form. Oxford: Oxford University Press, 2007. p. 1-8.

MICHELMAN, Frank I. Always Under Law. Constitutional Commentary, vol. 12, n. 2, p 227-47, Summer 1995. 
POLZIN, Monika. Constitutional identity, unconstitutional amendments and the idea of constituent power: the development of the doctrine of constitutional identity in German constitutional law. International Journal of Constitutional Law, vol. 14, n. 2, p. 411-38, Apr./Jun. 2016.

PREUSS, Ulrich K. Constitutional Revolution: The Link between Constitutionalism and Progress. Atlantic Highlands: Humanities Press, 1995.

PREUSS, Ulrich K. The implications of "eternity clauses": the German experience.' Israel Law Review, vol. 44, n. 3, p. 429-88, Nov./Feb. 2011-12. 429-88.

ROSENFELD, Michel. The Identity of the Constitutional Subject: Selfhood, Citizenship, Culture, and Community. Abingdon: Routledge, 2009.

ROZNAl, Yaniv. Unconstitutional constitutional amendments-the migration and success of a constitutional idea. American Journal of Comparative Law, vol. 61, n. 3, p. 657-720, summer, 2013.

ROZNAI, Yaniv. Unconstitutional Constitutional Amendments: The Limits of Amendment Powers. Oxford: Oxford University Press, 2017.

SCHMITT, Carl. Constitutional Theory. Durhnam: Duke University Press, 2007.

SIEYÈS, Emmanuel Joseph. What Is the Third Estate? Translated by M. Blondel. London: Pall Mall Press, 1963.

TAIWAN likely to pass constitutional amendment lowering voting age to 18 . Taiwan News, 19 Feb 2020. Available in: <https://www.taiwannews.com.tw/en/news/3878403>. Last visited: 04/04/2020.

TRIBE, Laurence $\mathrm{H}$. The puzzling persistence of process-based constitutional theories. Yale Law Journal, vol. 89, n. 6, p. 1063-80, 1980.

TWINING, William. Globalisation and Legal Scholarship. Nijmegen: Wolf Legal Publishers, 2011. YEH, Jiunn-rong. The Constitution of Taiwan: A Contextual Analysis. Oxford: Hart, 2016. 